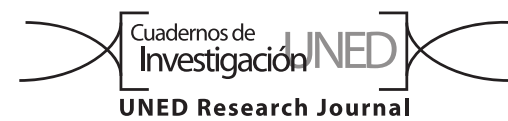

\title{
Physiological and bacteriological profile of the fish Clarias gariepinus (Siluriformes: Clariidae) chronically exposed to different concentrations of municipal waste leachate in Nigeria
}

\author{
Olufemi David Owolabi', Patricia Folakemi Omojasola ${ }^{2}$, Funmilola Janet Abioye' \& Olufunbi Praise Aina ${ }^{2}$ \\ 1. University of Ilorin, Department of Zoology, P.M.B. 1515, Ilorin 240003, Nigeria; olulabi47@yahoo.com, olulabi@unilorin.edu.ng \\ 2. University of Ilorin, Department of Microbiology, P.M.B. 1515, llorin 240003, Nigeria.
}

Received 18-X-2018 • Corrected 17-I-2019 • Accepted 30-I-2019

\begin{abstract}
Introduction: One of the most commonly used methods of waste management is landfilling, which has been a major environmental concern. Objective: To examine the effect of leachate on Clarias gariepinus. Methods: We tested Clarias gariepinus $(n=700)$ with varying concentrations of leachate $(0,10,15,20$ and 25\%) from the Amoyo dumpsite, llorin, Nigeria. After 28-day exposure, haematological, biochemical, bacteriological and histopathological assays were carried out. Results: $\mathrm{pH}$ ranged from 7,78 to 13,97; cadmium, iron, lead, manganese and zinc were 178-, 134-, 6248-, 400- and 3-fold, respectively, higher than the regulatory limits for waterbodies, while copper fell within the limits. Values of red blood cell, haemoglobin, packed cell volume, mean cell volume, mean cell haemoglobin, mean cell haemoglobin concentration, lymphocytes and monocytes were significantly lower than the control. Conversely, white blood cell, neutrophils and eosinophils increased in a concentration-dependent manner. There were tissue-specific differences in the responses of all biochemical parameters investigated except for protein that significantly decreased in all the tissues. 27 bacterial isolates classified into seven genera including Bacillus, Klebsiella, Pseudomonas, Staphylococcus, Acinetobacter, Escherichia and Micrococcus were recorded from the leachate and selected organs of $C$. gariepinus. The total bacterial, viable coliform and total counts in the leachate were $4,2 \times 10^{6} \mathrm{CFU} / \mathrm{mL}, 3,8 \times 10^{8} \mathrm{CFU} / \mathrm{mL}$, $3,6 \times 10^{6} \mathrm{CFU} / \mathrm{mL}$ and $2,7 \times 10^{8} \mathrm{CFU} / \mathrm{mL}$, respectively. The highest counts were recorded in the gills $\left(14,2 \times 10^{6} \mathrm{CFU} / \mathrm{mL}\right)$ and lowest in the muscle $\left(2,7 \times 10^{6} \mathrm{CFU} / \mathrm{mL}\right)$ at the highest and least concentration of the leachate, respectively. Most of the bacteria isolated from the leachate were also recovered from the fish organs. Escherichia coli had the highest frequency of occurrence (26\%). Conclusion: This study revealed that toxic constituents of the leachate elicited deleterious changes in the bacteriology and physiology of C. gariepinus.
\end{abstract}

Key words: Clarias gariepinus, leachate, haematological parameters, biochemical parameters, bacteria profile.
RESUMEN: "Perfil fisiológico y bacteriológico del pez Clarias gariepinus (Siluriformes: Clariidae) expuesto crónicamente a diferentes concentraciones de lixiviados de residuos municipales en Nigeria". Introducción: Uno de los métodos más utilizados para el manejo de residuos es el relleno sanitario, que ha sido una preocupación ambiental importante. Objetivo: Examinar el efecto del lixiviado sobre Clarias gariepinus. Métodos: Analizamos especímenes de Clarias gariepinus $(n=700)$ con concentraciones variables de lixiviado $(0,10,15,20$ y $25 \%$ ) en el vertedero de Amoyo, llorin, Nigeria. Después de 28 días de exposición, se realizaron ensayos hematológicos, bioquímicos, bacteriológicos e histopatológicos. Resultados: El pH varió de 7,78 a 13,97; cadmio, hierro, plomo, manganeso y zinc fueron 178, 134, 6 248, 400 y 3 veces, respectivamente, más altos que los límites regulatorios para cuerpos de agua, mientras que el cobre cayó dentro de los límites. Los valores de glóbulos rojos, hemoglobina, volumen de células empaquetadas, volumen celular medio, hemoglobina celular media, concentración media de hemoglobina celular, linfocitos y monocitos fueron significativamente más bajos que el control. Por el contrario, los glóbulos blancos, neutrófilos y eosinófilos aumentaron de una manera dependiente de la concentración. Hubo diferencias específicas de tejido en las respuestas de todos los parámetros bioquímicos investigados, excepto por la proteína que disminuyó significativamente en todos los tejidos. Veintisiete aislamientos bacterianos clasificados en siete géneros incluyendo Bacillus, Klebsiella, Pseudomonas, Staphylococcus, Acinetobacter, Escherichia y Micrococcus se registraron del lixiviado y órganos seleccionados de $C$. gariepinus. El total de bacterias, coliformes viables y recuentos totales en el lixiviado fueron $4,2 \times 10^{6} \mathrm{CFU} / \mathrm{mL}, 3,8 \times 10^{8} \mathrm{CFU} /$ $\mathrm{mL}, 3,6 \times 10^{6} \mathrm{CFU} / \mathrm{mL}$ and $2,7 \times 10^{8} \mathrm{CFU} / \mathrm{mL}$, respectivamente. Las cuentas más altas se registraron en las branquias $\left(14,2 \times 10^{6} \mathrm{UFC} / \mathrm{mL}\right)$ y las más bajas en el músculo $\left(2,7 \times 10^{6} \mathrm{UFC} / \mathrm{mL}\right)$ en la concentración más alta y la menor del lixiviado, respectivamente. La mayoría de las bacterias aisladas del lixiviado también se recuperaron de los órganos de los peces. Escherichia coli tuvo la mayor frecuencia de aparición (26\%). Conclusión: Este estudio reveló que los constituyentes tóxicos del lixiviado provocaron cambios perjudiciales en la bacteriología y fisiología de C. gariepinus.

Palabras clave: Clarias gariepinus, lixiviados, parámetros hematológicos, parámetros bioquímicos, perfil de bacterias. 
Several industries across the globe produce and utilize large quantities of products with corresponding increase in waste generated. Although the generation of wastes is a universal issue, the type, fate and amount of waste generated is dependent on societal, economic and technological advances (Imoh \& Udofia, 2011). Common solid waste products generated in Nigerian cities include food scraps, metals/cans, glass, ceramics, textiles, rubber, plastic, polythene bags, paper, wood among others (Ibrahim, Awomuti, \& Ajibade, 2012). Methods commonly employed in the management of these wastes include incineration, composting, recycling, dumping into water bodies and landfilling (Bakare, Alabi, Gbadebo, Ogunsuyi, \& Alimba, 2013). Among these, however, landfilling has proven to be the most commonly used method of waste management globally (Laneret, Crest, Scharff, Morris, \& Barlaz, 2012).

The physicochemical and microbiological processes occurring in landfills convert solid wastes into different compounds. These compounds, in turn, combine with percolating rain water to form a contaminant-rich aqueous solution called 'leachate' (Kurniawan, Lo, \& Chan, 2006). Leachate have been characterised with heavy metals such as cadmium, chromium, lead, copper, zinc, nickel and other chemical compounds such as ammonium, calcium, magnesium, potassium, sodium, iron, sulphates and chlorides (Christensen et al., 2001). These chemical compounds are known to induce toxicity in aquatic organisms (Oliveira, Silva, \& Martinez, 2014; Budi, Suliasih, Othman, Heng, \& Surif, 2016).

Biologically based methods have successfully been used in the toxicological assessment of leachates in aquatic organisms (Ribé et al., 2012), however, enzymatic and histopathological biomarkers are seldom used (Oliveira et al., 2014).The induction or inhibition of biomarkers is a good approach to measuring the potential impact of environmental toxicants on aquatic organisms. However, dearth of information exists on the application of biomarkers in the evaluation of leachate toxicity in fish (Tsarpali \& Dailianis, 2012; Bakare et al., 2013). Among these, data on the use of biomarkers to assess leachate effects on Nigerian freshwater fish fauna are limited. Available information is restricted to the report of Oshode, Bakare, Adeogun, Efuntoye, and Sowunmi (2008) and Aderemi, Adewumi, and Otitoloju (2012) on changes in the haematology and histology of Clarias gariepinus, respectively as biomarkers of response to leachate exposure. Besides, these authors only made available scanty haematological and histological biomarkers, none of which have reported the use of enzymatic/biochemical responses as biomarkers to leachate exposure in C. gariepinus.

Fish are always in close contact with microorganisms with which they inhabit aquatic environment (Olugbojo \& Ayoola, 2015).These microorganisms are found resident in different parts of fish such as skin, mouth, gill and gut-parts that are in direct contact with the water body, where they prevent other pathogenic organisms from colonizing the fish (Olojo, Amusa, Osho, \& Badejo, 2010). Hence, changes in microbiological profile can be a good indicator of diseased condition in fish. Oshode et al. (2008) showed that the microbial population of Aba-Eku landfill leachate, Ibadan to which C. gariepinus were exposed ranged from $0,3 \times 10^{6}$ to $9,2 \times 10^{9} \mathrm{CFU} / \mathrm{mL}$, but the microbial population of the same fish exposed to Soluos (II) landfill leachate, Lagos was $1,26 \times 10^{5} \mathrm{CFU} / \mathrm{mL}$; suggesting that leachates from the two locations may be of varying composition. If this proposition holds true, it follows that landfill leachates of different chemical constituents may enhance different induction or inhibition of biomarkers in fish. Prior to this study, the microbial characteristics of leachate from landfills in llorin metropolis has not been ascertained; thus obscuring the understanding of the public health risks that municipal solid wastes leachate may pose to aquatic organisms as well as humans and livestock.

The use of fish as sentinel in the ecotoxicological assessment of water-borne contaminants is pertinent because fish and man are closely linked in the food chain. The African sharp tooth catfish, $C$. gariepinus constitutes one of the most important fish fauna in tropical waters. They are particularly endemic in Nigerian freshwaters, hence their suitability for baseline evaluation of water-borne contaminants and commonly used in experimental models due to its all-year round availability and adaptability to laboratory conditions.

The lack of proper management of municipal solid wastes (MSW) from which large amounts of deleterious and toxic substances are released into the environment is a major concern in Nigeria (Oshode et al., 2008). Considering the serious health risks that the contamination of water by leachates may pose to aquatic system and its resident fish species, as well as humans and farm animals that depend on water for fish and drinking purposes, this study is aimed at evaluating the impacts of MSW leachates from Amoyo dumpsite, Ilorin metropolis on the bacteriological and physiological profiles of $C$. gariepinus. Such investigation may provide useful information for formulating policy that could be used to protect aquatic living resources, human health and environment. 


\section{MATERIALS AND METHODS}

Leachate sampling site, collection and handling: Leachate samples were collected from Amoyo municipal solid wastes (MSW) dumpsite located at $80^{\circ} 26^{\prime} 00^{\prime \prime} \mathrm{N}$ $\& 80^{\circ} 30^{\prime} 00^{\prime \prime} \mathrm{E}$, Ilorin, Kwara State, Nigeria. The site which covers approximate surface area of $3,63 \times 10^{6} \mathrm{~m}^{2}$ with average dump thickness of about $7,7 \mathrm{~m}$, was originally an excavations pit for laterite soil opened for the dumping of refuse in 2008 and is still being used by the Kwara State Waste Management Corporation (KWMC) till date. It receives mainly domestic, hazardous household and commercial solid wastes from auto-battery, quarry, and ceramic industries. The dumpsite is directly behind a river with the leachate making entry into the waterbody. The raw leachates, approximately $5 \mathrm{~L}$ per sample were collected forthnightly between July and September, 2016 using a pre-sterilized plastic container from a sampling point (Tsarpali \& Dailianis, 2012); and transferred to the laboratory. Samples were filtered to remove debris and stored at $4^{\circ} \mathrm{C}$ prior use (Tsarpali \& Dailianis, 2012). This was considered the stock solution for the chronic toxicity test.

Physicochemical/heavy metal analysis: the physicochemical parameters and heavy metal content of the leachate samples were determined prior to the experiment. The HQ40 multi-meter probe (Hach Lange $\mathrm{GmbH}$, Germany) was used to determine physical parameters such as $\mathrm{pH}$, electrical conductivity and total dissolved solids (TDS), while APHA (1998) procedure was used to estimate chemical parameters such as biological oxygen demand (BOD), chemical oxygen demand (COD), nitrates $\left(\mathrm{NO}_{3}{ }^{-}\right)$and sulphates $\left(\mathrm{SO}_{4}{ }^{2}\right)$.To the leachate samples, $5 \mathrm{HNO}_{3}$ was added to acidify the samples. The acidified samples were then stored at $4^{\circ} \mathrm{C}$ prior evaluation (Tsarpali \& Dailianis, 2012). Perkin Elmer Analyst atomic absorption spectrometer (AAS) was used to determine the level of copper $(\mathrm{Cu})$, cadmium $(\mathrm{Cd})$, iron $(\mathrm{Fe})$, lead $(\mathrm{Pb})$ and zinc $(\mathrm{Zn})$ in the samples. Authentication of metal analysis was done using a known concentrations of each metal examined.

Fish collection and handling: Juvenile $C$. gariepinus ( $\mathrm{n}=700$, average weight: $10,00 \pm 0,30 \mathrm{~g}$ and average standard length: $6,00 \pm 0,1 \mathrm{~cm}$ ) were procured from commercial hatcheries in Ilorin, Kwara State, Nigeria. The fish were conveyed in an aerated black tank to the laboratory without any mechanical injury. The fish were kept in constantly aerated borehole water (dissolved oxygen $7,89 \pm 1,26 \mathrm{mg} / \mathrm{L}, \mathrm{pH} 7,12 \pm 0,67$, temperature $22,41 \pm 1,84^{\circ} \mathrm{C}$ ) in the laboratory for two weeks for the purpose of acclimatisation. During this period, they were fed twice daily with commercial feed pellet at $3 \%$ body weight. Water was renewed every $24 \mathrm{~h}$ while maintaining a $12 \mathrm{~h}$ light: $12 \mathrm{~h}$ dark period.

Experimental procedure for the exposure of $C$. gariepinus to leachate: Five chronic concentrations of the leachate $(0,10,15,20$ and $25 \%)$ were prepared through serial dilution for the definitive test after conducting a range finding test. Three replicates of ten acclimated fishes of equal weight and size were treated with each of the concentrations for 28 days; and the respective leachate media were renewed every $24 \mathrm{~h}$. Fishes were fed daily with commercial feed pellets at a rate of $3 \%$ body weight. The experiment was carried out using a semi-static method to keep the toxicant concentration constant (Reish \& Oshida, 1987). Quality parameters of the test media to which C. gariepinus were exposed such as dissolved oxygen (DO), temperature and $\mathrm{pH}$ were monitored throughout the experimental period using a digital CS-C933T Electrochemistry multimetre (Topac Instrument, Inc., USA). Conductivity of the media was measured using conductivity metre (Eutech EC Tester 11 Pocket tester) and BOD was determined using a BOD metre (Aqualytic Sensor System, AL606).

Blood sampling and determination of haematological parameters: The procedure for blood collection was as described by Owolabi (2011). RBC and WBC counts were estimated using Neubauer haemocytometer method (Dacie \& Lewis, 2001). Packed cell volume (PCV) was determined by the microhaematocrit method (Dacie \& Lewis, 2001). Red blood cell indices (mean cell volume (MCV), mean cell haemoglobin $(\mathrm{MCH})$, and mean cell haemoglobin concentration (MCHC) were estimated using the formulae of Clark, Whitmore, and McMahon (1979). Neutrophil and lymphocytes were identified and estimated following the procedure of Dacie and Lewis (2001).

Preparation of tissue supernatant and determination of biochemical parameters: Approximately, $0,5 \mathrm{~mL}$ aliquots of blood were centrifuged at $350 \mathrm{~g}$ for $5 \mathrm{~min}$ using refrigerated centrifuge in order to separate serum for biochemical analysis. The fish were dissected to remove the gills and the liver. One gramme $(1 \mathrm{~g})$ each of the gill and liver was weighed and homogenized with $5 \mathrm{~mL}$ of $0,25 \mathrm{M}$ sucrose solution in ice-cold condition. The homogenate of each tissue was divided into two portions; the first one, approximately $150-200 \mu \mathrm{g} / \mathrm{L}$ was centrifuged at $14700 \mathrm{~g}$ and $4^{\circ} \mathrm{C}$ for $20 \mathrm{~min}$ to obtain the supernatant. 
This was used as resource base for the analysis of alanine aminotransaminase (ALT), aspartate aminotransaminase (AST), superoxide dismutase (SOD), lactodehydrogenase (LDH) and acetylcholinesterase (AChE). Serum and tissue activities of ALT and AST were determined by the procedure of Reitman and Frankel (1957). SOD was estimated using Misra and Fridovish (1972) procedure, while LDH was assayed following the method of DGKC (1970). Determination of AChE activity was as described by Dos Santos et al. (2005). Lipid peroxidation was estimated by a thiobarbituric acid reactive substance (TBARS) assay (Glusczak et al., 2011). The second portion of the homogenates was added to $8,1 \%$ sodium dodecyl sulfate (SDS) and 2,5M acetic acid $(\mathrm{pH}=3,34)$. Subsequently, $0,8 \%$ thiobarbituric acid was added to make a final volume of $2,0 \mathrm{~mL}$. The mixture was put in a microcentrifuge and incubated at $95^{\circ} \mathrm{C}$ for $90 \mathrm{~min}$. After cooling, it was centrifuged at $5000 \mathrm{~g}$ for $10 \mathrm{~min}$ and optimal density established at 532nm. TBARS levels were expressed as nmol*MDA/mg (Buege \& Aust, 1978). Protein content was estimated by Lowry, Rosebrough, Farr, and Randall (1951) method, while glucose was estimated using the procedure of Trinder (1969).

Histopathological assay: The gills and liver of leachate-exposed fish from each concentration were removed and fixed in aqueous Bouin's fluid for 24 hours at room temperature. The tissues were washed in water and dehydrated in different grades of alcohol (i.e. 70, 80, 90 and $100 \%$ ) consecutively and left for one hour, while in the $100 \%$ alcohol; it was left for two hours. Tissues were then cleared in xylene and infiltrated in the paraffin wax. Sections of 4-6 $\mu \mathrm{g} / \mathrm{l}$ were prepared from paraffin wax using a rotary microtome. The sections were then stained with Haematoxylin-Eosin and histopathological lesions examined and photomicrographic impressions taken, using Carl Zeiss binocular microscope (Axiophot, Germany).

\section{Microbiological analysis:}

Total bacterial count: The skin, gills and muscles of the test organisms were analysed microbiologically. Aseptically, $1 \mathrm{~g}$ of fish skin from each concentration was scraped and ground, employing a sterile mortar and pestle. Before the fish body cavity was opened, the skin was surface sterilized with $70 \%$ ethanol after which the body cavity was opened as described by Buras, Duek, and Niv (1985). A window was opened on the side of the fish through which the muscles were harvested. This was subsequently homogenized and serially diluted. One $\mathrm{mL}$ aliquots from $10^{-5}$ to $10^{-9}$ dilutions were chosen and plated on the appropriate media. Standard disposable Petri dishes (90mm; Graceland, England) were used for plating on Nutrient agar and MacConkey agar for isolation. The plates were incubated at $37^{\circ} \mathrm{C}$ for $24 \mathrm{~h}$. The process was repeated for the gills and muscle, with control experiments for all (Adewoye \& Adegunlola, 2010).

Bacterial identification: The isolates were characterized and identified based on colonial morphology, staining reaction and molecular techniques.

Molecular characterization of isolates: Characterization of isolates was done using molecular biology technique. This was categorized into three main steps: DNA extraction/isolation, polymerase chain reaction (PCR) and DNA sequencing.

Statistical analysis: Results were expressed as mean \pm standard deviation (SD). Data were statistically analysed using analysis of variance (ANOVA) followed by Tukey's test and values of $p<0,05$ were considered significant. The data were subjected to one way analysis (ANOVA) and comparisons made at $95 \%$ confidence level $(\alpha=0,05)$.

Ethical, conflict of interest and financial statement: Animal maintenance and experimental procedures were conducted in accordance with the Guide for Use and Care of Laboratory Animals provided by the Committee for the update of the guide for the care and use of Laboratory Animals and effort were made to minimize animal suffering and reduce number of specimens. The experimental protocol was approved by the Ethical Committee of the University of Ilorin and carried out in accordance with the legislation of the European Parliament and Council for the protection of vertebrate animals used for experimental and scientific purposes. Also, the authors declare that there are no conflicts of interest of any kind; that no financial grant from any funding agency in the public, commercial or not-for-profits sectors was received; and that they fully agree with the final edited version of the article. A signed document has been filed in the journal archives.

\section{RESULTS}

The physicochemical properties and heavy metals of the MSW-leachate sampled from Amoyo dumpsite, Ilorin, Nigeria, are shown in Table 1. The $\mathrm{pH}$ of the sample was alkaline $(13,87 \pm 0,16)$ and very high levels of BOD $(2684 \pm 210,01)$, COD (3 422 $\pm 413,02)$, chloride $(2790 \pm 125,86)$, nitrate $(52,15 \pm 9,01)$ and all the heavy metals except copper were recorded. These parameters deviated from the permissible limits of some regulatory 
TABLE 1

Physicochemical parameters and heavy metal content of MSW-leachate from Amoyo dumpsite, llorin, Nigeria

\begin{tabular}{|c|c|c|c|c|c|}
\hline \multirow{2}{*}{ Physicochemical parameter } & \multirow{2}{*}{ Value } & \multicolumn{4}{|c|}{ Regulatory limits } \\
\hline & & NIS (2007) & NESREA (2011) & USEPA (2011) & WHO (2011) \\
\hline $\mathrm{pH}$ & $13,87 \pm 0,16$ & $6,50-9,50$ & $6,00-9,00$ & $6,50-8,50$ & $6,50-8,50$ \\
\hline Electrical Conductivity (EC) & $612,02 \pm 80,02$ & 1000 & $\mathrm{~N} / \mathrm{A}$ & $\mathrm{N} / \mathrm{A}$ & 1000 \\
\hline Total dissolved solids (TDS) & $138,21 \pm 34,01$ & 500 & 500 & 500 & $<1000$ \\
\hline BOD & $2684 \pm 210,01$ & $\mathrm{~N} / \mathrm{A}$ & 50.00 & 250 & $\mathrm{~N} / \mathrm{A}$ \\
\hline COD & $3422 \pm 413,02$ & $\mathrm{~N} / \mathrm{A}$ & 90 & 410 & $\mathrm{~N} / \mathrm{A}$ \\
\hline Total alkalinity & $13,63 \pm 0,09$ & $\mathrm{~N} / \mathrm{A}$ & 150 & 20 & N/A \\
\hline Sulphate $\left(\mathrm{SO}_{4}\right)$ & $114,52 \pm 20,01$ & 100 & $\mathrm{~N} / \mathrm{A}$ & $\mathrm{N} / \mathrm{A}$ & 500 \\
\hline Nitrate $\left(\mathrm{NO}_{3}{ }^{2}\right)$ & $52,15 \pm 9,01$ & 50 & 10 & 10 & 50 \\
\hline Chloride & $2790 \pm 125,86$ & 250 & $\mathrm{~N} / \mathrm{A}$ & 250 & $\mathrm{~N} / \mathrm{A}$ \\
\hline \multirow{2}{*}{ Metal content } & \multirow{2}{*}{ Value } & \multicolumn{4}{|c|}{ Regulatory limits } \\
\hline & & NIS (2007) & NESREA (2011) & USEPA (2011) & WHO (2011) \\
\hline Copper (Cu) & $0,21 \pm 0,01$ & 1,000 & 0,5 & 1,3 & 2,000 \\
\hline Cadmium (Cd) & $1,78 \pm 0,01$ & 0,003 & 0,2 & 0,01 & 0,003 \\
\hline Iron (Fe) & $40,28 \pm 2,62$ & 0,300 & N/A & 0,3 & $\mathrm{~N} / \mathrm{A}$ \\
\hline Lead (Pb) & $62,48 \pm 3,01$ & 0,01 & 0,05 & 0,02 & 0,01 \\
\hline Manganese (Mn) & $20,02 \pm 2,91$ & & 0,2 & 0,05 & N/A \\
\hline Zinc $(Z n)$ & $9,04 \pm 0,01$ & 3,000 & & 5 & $\mathrm{~N} / \mathrm{A}$ \\
\hline
\end{tabular}

$\mathrm{BOD}=$ Biological Oxygen Demand, $\mathrm{COD}=$ Chemical Oxygen Demand, NIS=Nigeria Industrial Standard, NESREA=National Environmental Standard Regulation Enforcement Agency, USEPA=United States Environmental Protection Agency. WHO=World Health Organization, N/A=Not Available.

bodies, thus showing the high level of contamination of the leachate. However, the values recorded for EC $(612,02 \pm 80,02)$, TDS $(138,21 \pm 34,01)$ and $\mathrm{Cu}(0,21 \pm 0,01)$ are within such approved standards.

C. gariepinus exposed to sublethal concentrations of leachate showed significantly decreased $(p<0,05)$ levels of RBC, HB, PCV and all the erythrocyte indices (MCV, $\mathrm{MCH}$ and $\mathrm{MCHC}$ ) in the serum, compared with those in the control. Conversely, increased WBC activities in a concentration-dependent manner were recorded in the serum of leachate-exposed fish, with respect to those observed in the control groups. The neutrophils and eosinophils levels followed a similar definite trend of significant increase $(p<0,05)$ as the concentration of leachate increased, with the lowest activity $(39,67 \pm 0,58$ and $0,90 \pm 0,12 \%)$; insignificantly $(p<0,05)$ different from the control recorded at $10,00 \%$ concentration, respectively. Lymphocytes and monocytes decreased as concentration of leachate increased with the lowest values recorded at the highest concentration of leachate (Table 2).

The changes in tissue biochemical parameters of $C$. gariepinus exposed to varying concentrations of Amoyo MSW leachate is shown in Table 3. The levels of transaminase enzymes (ALT and AST), SOD, AChE and glycogen in the blood serum exhibited a significant $(p<0,05)$ increasing trend from control to the highest concentration of leachate, while the trend in LDH and MDA activities were not significantly different $(p<0,05)$ from control. In the gills and liver, the transaminases and glycogen, showed a significant decreasing trend compared to the control, while LDH, SOD and MDA activities significantly increased relative to the control. The level of MDA was higher in gills than in liver. AChE activity in the gills was inhibited with increasing concentration of leachate, while in the liver it was significantly induced as the concentration of leachate increased. In all the tissues, protein level significantly decreased $(p<0,05)$ compared to their corresponding control groups.

A total of 27 bacterial isolates belonging to sevengenera namely Bacillus, Klebsiella, Acinetobacter, Pseudomonas, Staphylococcus, Escherichia and Micrococcus were recorded from the leachate and selected organs of Clarias gariepinus (Table 4). The samples were positive for potential pathogenic species and toxin producing organisms. It is significant to note that while no bacteria were detected in the muscle of the control fish samples, bacteria were isolated from the muscles of the fish exposed to the leachate (Table $5 \& 6$ ). The bacterial load of the gill was 


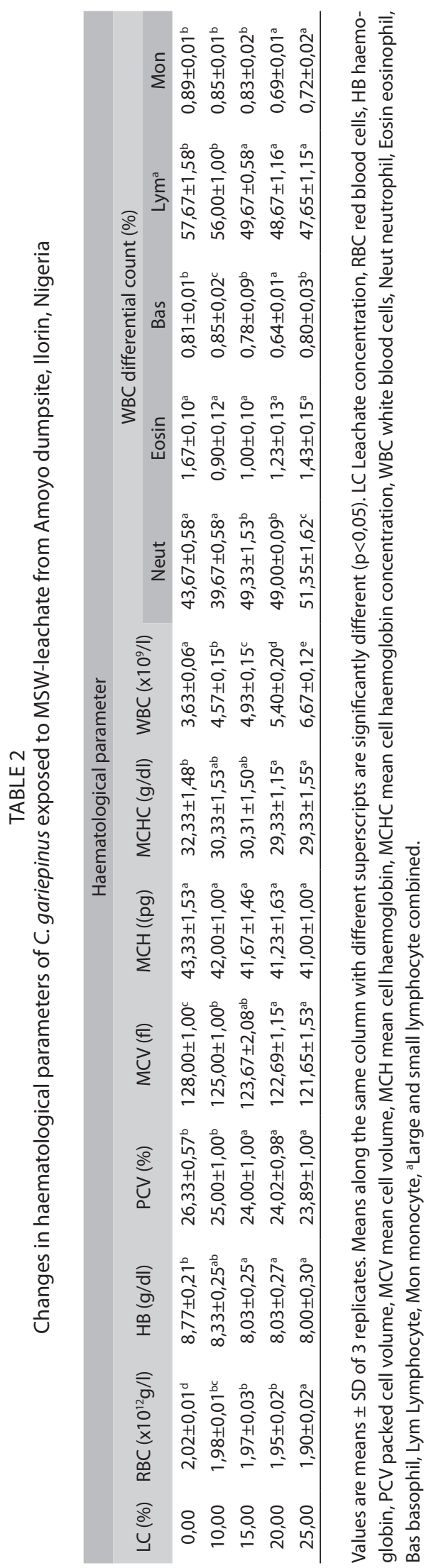

higher than the other parts of the fish with the least in the muscle (Table $5 \& 6$ ). This observation was recorded on all the days of sampling (Table 6).

The cross sections of gills and liver of fish chronically exposed to leachate for 28 days is shown in Figs. 1 and 2 . Gills from the control fish was found with normal architecture such as primary and secondary lamella (Fig. 1a). In leachate-exposed fish (Fig. 1b-e), pathological changes such as cellular erosion, necrosis, swelling of lamella, fatty degeneration, abnormal gill tip, and epithelia hyperplasia were observed. However, these pathological changes were more pronounced as concentration of leachate increased. Apart from the cellular erosion and infiltration observed in the gill of fish exposed to 15 and $20 \%$ leachate, abnormal gill tip, severe necrosis and fatty degeneration were observed in $20 \%$ leachate-treated fish (Fig. 1d) with an extensive hyperplasia and fatty degeneration observed in $25 \%$ leachate-treated fish. The section of fish from the control had their hepatocytes arranged orderly with uniform nuclei morphology (Fig. 2a). Fish exposed to the lowest concentration of leachate showed signs of early focal fibrosis and mild congestion of sinusoid (Fig. 2b).In 15-25\% leachate-treated fish (Fig. $2 \mathrm{c}-\mathrm{e})$, melanomacrophage centre, congestion of sinusoid and cellular infiltration were common pathological alterations observed. However, these pathological changes were also more intense with increase in leachate concentrations.

\section{DISCUSSION}

Physicochemical parameters of leachate: The characterization of leachate is mainly based on the determination of its physicochemical components (Tsarpali \& Dailianis, 2012) due to the difficulty in determining the large number of its organic and inorganic compounds, including toxic and carcinogenic chemicals (Kulikowska \& Klimiuk, 2008). The alkaline nature of the leachate ( $\mathrm{pH}$ $13,87 \pm 0,16)$ could be due to the fermentation process occurring in the landfill. According to McBean, Rovers, and Farquhar (1995), alkaline pH enhances the production of methanogens which convert the organic components of leachate to methane gas. This fermentation process raises a serious ecological concern because of the air pollution that may usually occur at dump site due to spontaneous combustion during the dry season of the year. The high levels of organic and inorganic contamination of the leachate as reflected by high concentrations of BOD and COD agree with the observations of 2006 and Oshode et al. (2008). The BOD value is above the maximum allowable limit $(3,0-6,0 \mathrm{mg} / \mathrm{l})$ recommended 
TABLE 3

Changes in biochemical parameters of C. gariepinus exposed to MSW-leachate from Amoyo dumpsite, Ilorin, Nigeria

\begin{tabular}{|c|c|c|c|c|c|c|c|c|c|}
\hline \multirow[b]{2}{*}{ Tissue } & \multirow[b]{2}{*}{ LC (\%) } & \multicolumn{8}{|c|}{ Biochemical parameter } \\
\hline & & ALT (IU/I) & AST (IU/I) & LDH (IU/I) & SOD (IU/I) & AChE (IU/I) & $\begin{array}{c}\text { MDA } \\
\text { (nmol MDA.mg) }\end{array}$ & $\begin{array}{l}\text { Glycogen } \\
(\mathrm{mmol} / \mathrm{l})\end{array}$ & Protein $(\mathrm{g} / \mathrm{l})$ \\
\hline \multirow[t]{5}{*}{ Blood } & 0,00 & $20,00 \pm 2,00^{\mathrm{a}}$ & $102,00 \pm 0,00^{\mathrm{a}}$ & $146,33 \pm 1,08^{\mathrm{a}}$ & $173,67 \pm 3,51^{\mathrm{a}}$ & $15,00 \pm 0,00^{\mathrm{a}}$ & $4,67 \pm 0,58^{\mathrm{a}}$ & $1,40 \pm 0,00^{\mathrm{a}}$ & $36,00 \pm 0,00^{c}$ \\
\hline & 10,00 & $59,00 \pm 1,73^{b}$ & $112,00 \pm 0,00^{\mathrm{b}}$ & $193,33 \pm 3,06^{\mathrm{ab}}$ & $187,67 \pm 4,51^{b}$ & $18,00 \pm 0,00^{b}$ & $5,00 \pm 0,00^{\mathrm{ab}}$ & $2,00 \pm 0,20^{b}$ & $32,00 \pm 0,00^{b}$ \\
\hline & 15,00 & $64,00 \pm 0,00^{c}$ & $169,33 \pm 0,72^{c}$ & $203,00 \pm 2,00^{\mathrm{ab}}$ & $213,00 \pm 2,00^{c}$ & $21,33 \pm 0,58^{c}$ & $5,00 \pm 0,00^{\mathrm{ab}}$ & $2,70 \pm 0,20^{c}$ & $30,00 \pm 0,00^{b}$ \\
\hline & 20,00 & $68,67 \pm 1,53^{d}$ & $185,67 \pm 1,15^{d}$ & $221,33 \pm 0,58^{\mathrm{ab}}$ & $234,00 \pm 0,00^{d}$ & $21,67 \pm 2,52^{c}$ & $6,00 \pm 1,00^{\mathrm{bc}}$ & $2,77 \pm 0,15^{c}$ & $24,00 \pm 2,00^{\mathrm{a}}$ \\
\hline & 25,00 & $77,67 \pm 1,53^{e}$ & $221,00 \pm 1,00^{e}$ & $246,33 \pm 1,53^{b}$ & $241,00 \pm 1,00^{\mathrm{e}}$ & $26,67 \pm 1,54^{d}$ & $7,00 \pm 1,00^{c}$ & $4,17 \pm 0,15^{d}$ & $22,00 \pm 2,00^{\mathrm{a}}$ \\
\hline \multirow[t]{5}{*}{ Gill } & 0,00 & $77,33 \pm 1,15^{\mathrm{e}}$ & $100,00 \pm 0,00^{\mathrm{b}}$ & $106,00 \pm 2,00^{\mathrm{a}}$ & $151,34 \pm 1,53^{\text {a }}$ & $93,00 \pm 2,00^{d}$ & $5,00 \pm 0,00^{\mathrm{a}}$ & $3,50 \pm 0,30^{d}$ & $42,00 \pm 0,00^{c}$ \\
\hline & 10,00 & $64,00 \pm 1,00^{d}$ & $110,21 \pm 2,05^{c}$ & $163,32 \pm 1,15^{b}$ & $182,67 \pm 2,52^{b}$ & $86,00 \pm 1,00^{c}$ & $8,37 \pm 0,58^{b}$ & $3,33 \pm 0,42^{c d}$ & $36,00 \pm 2,00^{b}$ \\
\hline & 15,00 & $46,65 \pm .2,08^{c}$ & $113,09 \pm 1,58^{c}$ & $173,67 \pm 1,53^{c}$ & $243,00 \pm 1,00^{d}$ & $74,67 \pm 1,53^{b}$ & $10,00 \pm 1,00^{b}$ & $2,90 \pm 0,00^{b c}$ & $35,00 \pm 0,00^{b}$ \\
\hline & 20,00 & $42,33 \pm 2,52^{b}$ & $98,52 \pm 1,23^{b}$ & $174,00 \pm 2,11^{c}$ & $262,67 \pm 2,52^{\mathrm{e}}$ & $77,33 \pm 1,53^{b}$ & $10,09 \pm 1,00^{b}$ & $2,70 \pm 0,00^{\mathrm{ab}}$ & $34,33 \pm 2,08^{b}$ \\
\hline & 25,00 & $36,67 \pm 1,53^{\mathrm{a}}$ & $79,62 \pm 1,44^{\mathrm{a}}$ & $180,31 \pm 2,52^{\mathrm{d}}$ & $214,00 \pm 2,00^{c}$ & $63,64 \pm 1,53^{\mathrm{a}}$ & $8,98 \pm 1,25^{b}$ & $2,27 \pm 0,15^{\mathrm{a}}$ & $14,92 \pm 0,00^{\mathrm{a}}$ \\
\hline \multirow[t]{5}{*}{ Liver } & 0,00 & $100,26 \pm 2,11^{\mathrm{e}}$ & $136,02 \pm 1,25^{\mathrm{e}}$ & $191,23 \pm 1,35^{\mathrm{a}}$ & $124,00 \pm 0,00^{\mathrm{a}}$ & $105,00 \pm 0,00^{\mathrm{a}}$ & $5,00 \pm 1,00^{\mathrm{a}}$ & $3,40 \pm 0,00^{c}$ & $41,00 \pm 0,00^{d}$ \\
\hline & 10,00 & $89,00 \pm 1,00^{d}$ & $92,25 \pm 1,00^{d}$ & $206,76 \pm 2,06^{b}$ & $181,00 \pm 1,00^{b}$ & $108,00 \pm 1,00^{\mathrm{a}}$ & $5,67 \pm 0,56^{\mathrm{ab}}$ & $3,03 \pm 0,25^{b}$ & $30,32 \pm 0,58^{c}$ \\
\hline & 15,00 & $68,43 \pm 1,62^{c}$ & $79,70 \pm 1,29^{c}$ & $217,24 \pm 2,03^{c}$ & $200,00 \pm 1,00^{c}$ & $115,00 \pm 0,00^{b}$ & $8,00 \pm 1,00^{\text {bc }}$ & $2,93 \pm 0,06^{b}$ & $29,67 \pm 2,52^{c}$ \\
\hline & 20,00 & $54,00 \pm 1,34^{b}$ & $65,00 \pm 1,00^{b}$ & $215,00 \pm 1,89^{c}$ & $219,32 \pm 1,63^{d}$ & $120,00 \pm 1,00^{\mathrm{b}}$ & $9,33 \pm 1,31^{c}$ & $2,60 \pm 0,00^{a}$ & $25,00 \pm 1,81^{b}$ \\
\hline & 25,00 & $35,76 \pm 1,00^{\mathrm{a}}$ & $46,23 \pm 0,98^{\mathrm{a}}$ & $238,62 \pm 2,36^{\mathrm{d}}$ & $236,33 \pm 1,64^{\mathrm{e}}$ & $122,14 \pm 1,45^{\mathrm{b}}$ & $8,00 \pm 1,22^{\mathrm{bc}}$ & $2,60 \pm 0,20^{\mathrm{a}}$ & $20,00 \pm 0,00^{\mathrm{a}}$ \\
\hline
\end{tabular}

Values are means $\pm S D$ of three replicates. Means along the same column with different superscripts are significantly different $(p<0,05)$. LC Leachate concentration,ALT Alanine aminotransaminase,AST Aspartate aminotransaminase, LDH Lactate dehydrogenase, SOD Superoxide dismutase, AChEAcetylcholinesterase,MDA Malondialdehyde.

TABLE 4

Complete Nucleotide Blast of genes of isolated bacteria from the leachate and selected organs of Clarias gariepinus chronically exposed to different concentrations of municipal leachate

\begin{tabular}{|c|c|c|c|c|}
\hline $\mathrm{S} / \mathrm{N}$ & Isolates & No of bases & Identity (\%) & Accession number \\
\hline 1 & Bacillus subtilis USMW11 & 1604 & 96 & KR856008.1 \\
\hline 2 & Bacillus subtilis USMW11 & 1604 & 96 & KR856008.1 \\
\hline 3 & Klebsiellapneumoniae AC29 & 1790 & 98 & CP010466.1 \\
\hline 4 & Pseudomonas aeruginosa DSM50071 & 1609 & 96 & СР012001.1 \\
\hline 5 & Klebsiellapneumoniae AC29 & 1790 & 98 & СР010466.1 \\
\hline 6 & Pseudomonas aeruginosa DSM50071 & 1609 & 96 & СР012001.1 \\
\hline 7 & Staphylococcus aureus HB53 & 1706 & 99 & KF863850.1 \\
\hline 8 & Staphylococcus aureus HB53 & 1706 & 99 & KF863850.1 \\
\hline 9 & Acinetobacter baumannii CLF94 & 1291 & 95 & СР007535.2 \\
\hline 10 & Pseudomonas aeruginosa DSM50071 & 1609 & 96 & СР012001.1 \\
\hline 11 & Acinetobacter baumannii CLF94 & 1291 & 95 & CP007535.2 \\
\hline 12 & Bacillus subtilis USMW11 & 1604 & 96 & KR856008.1 \\
\hline 13 & Staphylococcus aureus HB53 & 1706 & 99 & KF863850.1 \\
\hline 14 & Bacillus subtilis USMW11 & 1604 & 96 & KR856008.1 \\
\hline 15 & Microccocus sp.JSC54 & 1794 & 97 & KJ184908.1 \\
\hline 16 & Klebsiellapneumoniae AC29 & 1790 & 98 & СР010466.1 \\
\hline 17 & Escherichia coli EH57 & 1880 & 98 & EC100988.2 \\
\hline 18 & Escherichia coli EH57 & 1880 & 98 & EC100988.2 \\
\hline 19 & Microccocus sp.JSC54 & 1794 & 97 & KJ184908.1 \\
\hline 20 & Pseudomonas aeruginosa DSM50071 & 1609 & 96 & CP012001.1 \\
\hline 21 & Escherichia coli EH57 & 1880 & 98 & EC100988.2 \\
\hline 22 & Staphylococcus aureus HB53 & 1706 & 99 & KF863850.1 \\
\hline 23 & Pseudomonas aeruginosa DSM50071 & 160 & 96 & СР012001.1 \\
\hline 24 & Microccocus sp.JSC54 & 1794 & 97 & KJ184908.1 \\
\hline 25 & Escherichia coli EH57 & 1880 & 98 & EC100988.2 \\
\hline 26 & Staphylococcus aureus HB53 & 1706 & 99 & KF863850.1 \\
\hline 27 & Escherichia coli EH57 & 1880 & 98 & EC100988.2 \\
\hline
\end{tabular}



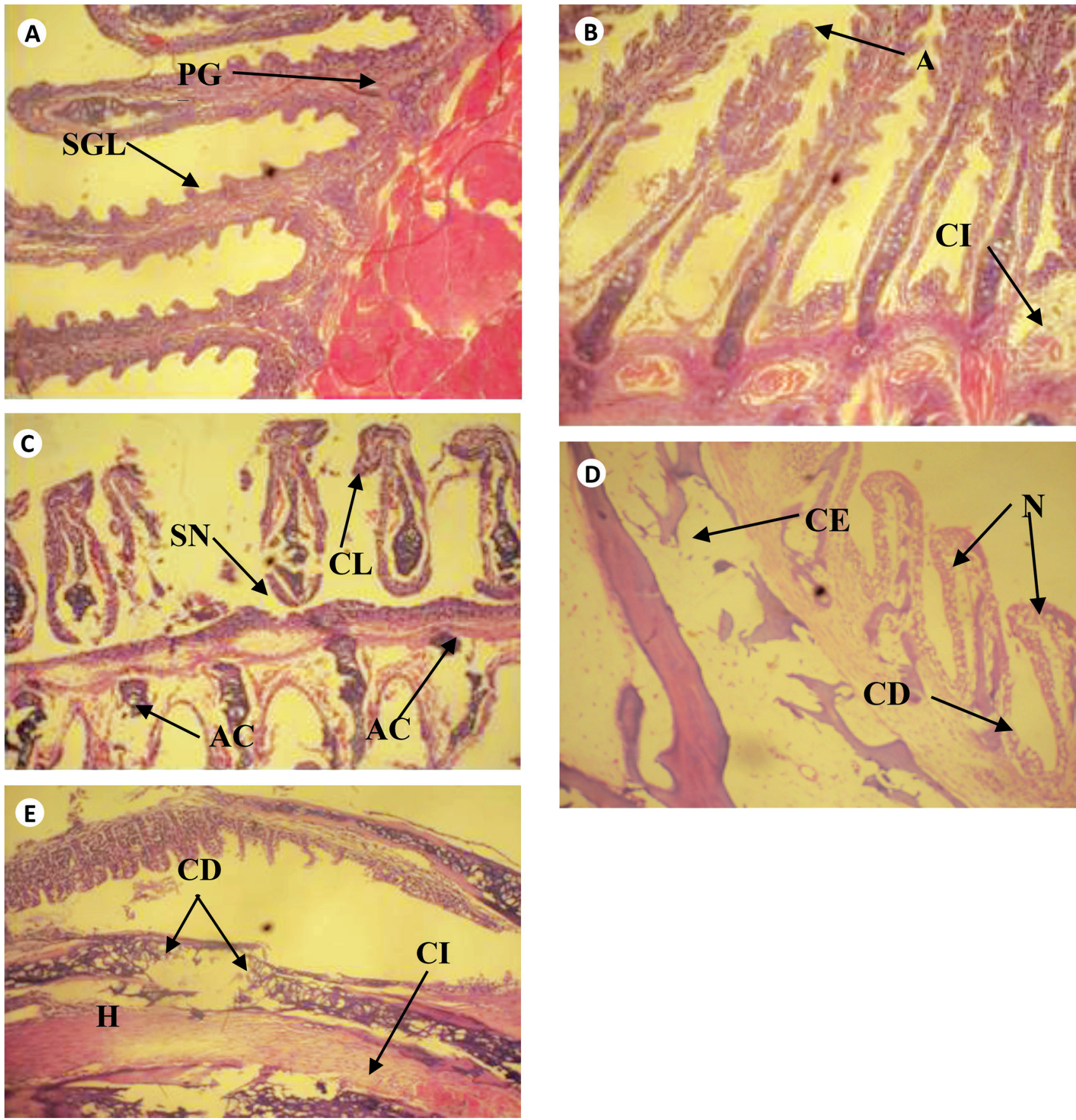

Fig. 1. Cross section of gill tissue of Clarias gariepinus exposed to different concentrations of leachate for 96h (H \& E x 200) showing (a) the normal architecture of control gill of Clarias gariepinus with Primary and secondary gill lamella. [PGL \& SGL]. (b) Area ofaneurysm $[\mathrm{A}]$ and cellular infiltration $[\mathrm{Cl}]$ of gill lamella. (c) Area of curling of lamella $[\mathrm{CL}]$, abnormal cartilage $[A C]$ and area of severe necrosis [SN]. (d) Area of cellular erosion [CE], necrosis [N] and cellular degeneration [CE]. (e) Area of hypertrophy [H], area of cellular erosion $[\mathrm{CE}]$, infiltration of cells $[\mathrm{Cl}]$ and cellular degeneration. [CD] 

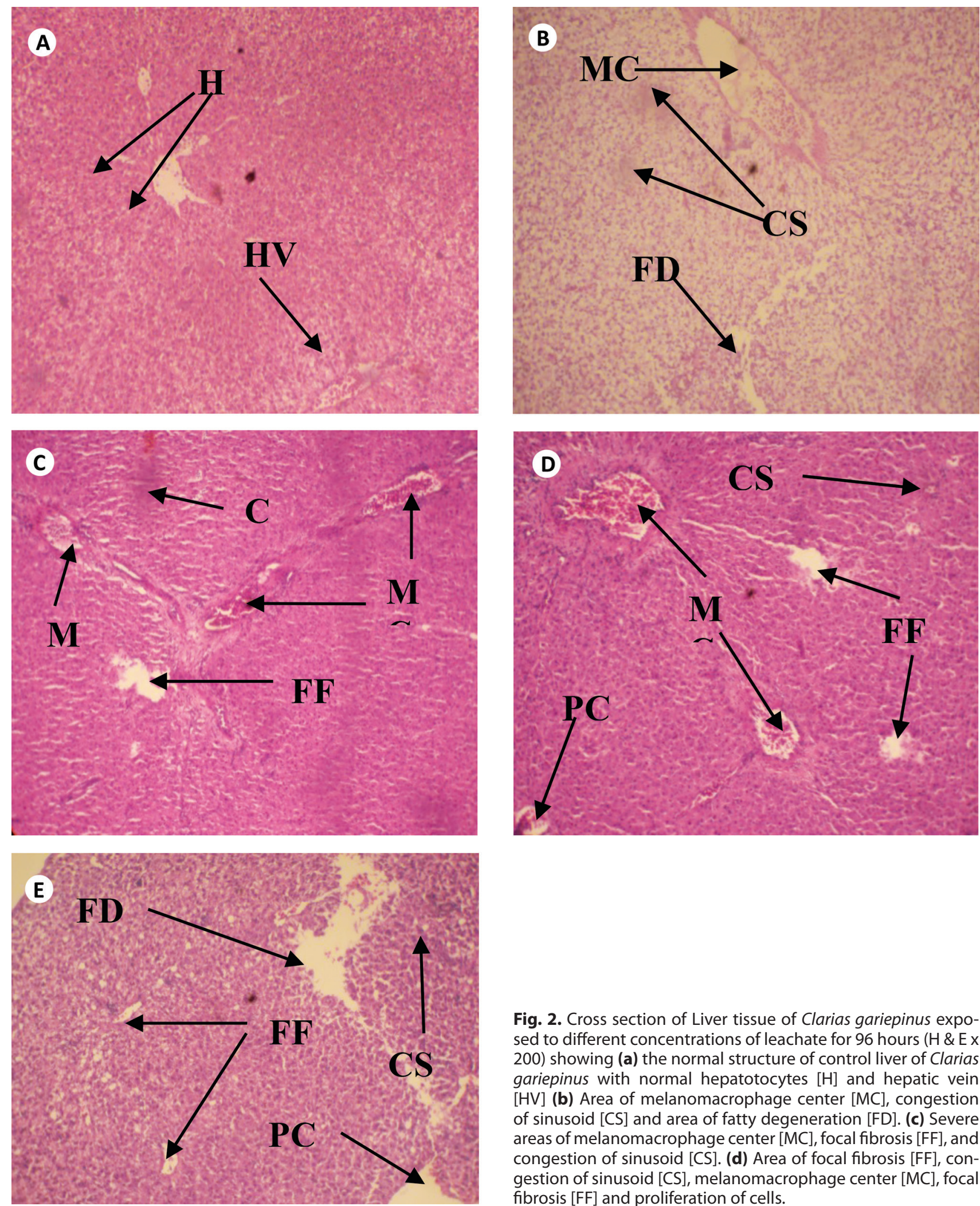

Fig. 2. Cross section of Liver tissue of Clarias gariepinus exposed to different concentrations of leachate for 96 hours (H \& Ex 200) showing (a) the normal structure of control liver of Clarias gariepinus with normal hepatotocytes $[\mathrm{H}]$ and hepatic vein [HV] (b) Area of melanomacrophage center [MC], congestion of sinusoid [CS] and area of fatty degeneration [FD]. (c) Severe areas of melanomacrophage center [MC], focal fibrosis [FF], and congestion of sinusoid [CS]. (d) Area of focal fibrosis [FF], congestion of sinusoid [CS], melanomacrophage center [MC], focal fibrosis [FF] and proliferation of cells. 
TABLE 5

Total bacteria count from the gill, muscle and skin of Clarias gariepinus exposed to chronic concentrations of MSW leachate from Amoyo dump site, llorin, Nigeria

\begin{tabular}{|c|c|c|c|c|c|c|c|c|c|c|c|c|c|c|c|c|c|c|c|c|c|c|c|c|c|c|c|c|c|c|}
\hline \multirow{4}{*}{ LC (\%) } & \multicolumn{30}{|c|}{ Total Viable /TotalColiform Count (x10 CFU/mL) } \\
\hline & \multicolumn{6}{|c|}{ Day 0} & \multicolumn{6}{|c|}{ Day 7} & \multicolumn{6}{|c|}{ Day 14} & \multicolumn{6}{|c|}{ Day 21} & \multicolumn{6}{|c|}{ Day 28} \\
\hline & \multicolumn{2}{|c|}{ G } & \multicolumn{2}{|c|}{ M } & \multicolumn{2}{|c|}{$S$} & \multicolumn{2}{|c|}{ G } & \multicolumn{2}{|c|}{ M } & \multicolumn{2}{|c|}{ S } & \multicolumn{2}{|c|}{ G } & \multicolumn{2}{|c|}{ M } & \multicolumn{2}{|c|}{$S$} & \multicolumn{2}{|c|}{ G } & \multicolumn{2}{|c|}{$M$} & \multicolumn{2}{|r|}{ S } & \multicolumn{2}{|c|}{ G } & \multicolumn{2}{|c|}{ M } & \multicolumn{2}{|c|}{$S$} \\
\hline & TC & TV & TC & TV & TC & TV & TC & TV & TC & TV & TC & TV & TC & TV & TC & TV & TC & TV & TC & TV & TC & TV & TC & TV & TC & TV & TC & TV & TC & TV \\
\hline Control & 0,6 & 0,8 & ND & ND & 0.6 & 0,3 & 1,8 & 2,2 & ND & ND & 1,3 & 1,2 & 2,3 & 2,5 & ND & ND & 1,8 & 1,6 & 1,7 & 1,8 & ND & ND & 1,9 & 1,4 & 1,2 & 1,3 & ND & ND & 1,2 & 0,9 \\
\hline 10,00 & 1,2 & 0,7 & 0,9 & 0,1 & 1,2 & 0,6 & 5,7 & 4,9 & 2,7 & 1,2 & 4,5 & 2,3 & 6,9 & 5,7 & 3,0 & 1,4 & 4,7 & 2,5 & 7,1 & 5,8 & 2,9 & 1,6 & 4,7 & 2,5 & 7,8 & 6,1 & 3,3 & 1,7 & 5,1 & 2,7 \\
\hline 15,00 & 1,8 & 1,0 & 1,5 & 0,3 & 1,9 & 0,7 & 6,8 & 5,5 & 2,9 & 1,6 & 4,7 & 2,7 & 7,8 & 6,9 & 3,0 & 1,7 & 5,0 & 2,9 & 8,4 & 7,4 & 3,2 & 1,9 & 5,4 & 2,9 & 9,7 & 7,9 & 3,7 & 2,1 & 5,9 & 3,1 \\
\hline 20,00 & 2,8 & 1,2 & 2,1 & 0,5 & 2,7 & 0,9 & 8,6 & 7,8 & 3,5 & 1,9 & 5,3 & 3,4 & 9,5 & 8,1 & 4,0 & 2,2 & 6,0 & 3,7 & 10,5 & 8,7 & 3,9 & 2,4 & 5,7 & 3,7 & 11,8 & 8,9 & 4,2 & 2,7 & 6,4 & 3,9 \\
\hline 25,00 & 3,2 & 1,6 & 2,5 & 0,8 & 3,0 & 1,2 & 9,7 & 8,2 & 3,9 & 2,3 & 6,3 & 4,2 & 10,8 & 8,7 & 4,0 & 2,7 & 6,7 & 3,9 & 13,5 & 9,5 & 4,5 & 2,7 & 6,9 & 4,2 & 14,2 & 9,7 & 5,1 & 3,2 & 7,2 & 4,5 \\
\hline
\end{tabular}

G=Gills; M=muscles; S=skin; TV=Total Viable Count; TC=Total Coliform Count; LC=Leachate Concentration; ND=Not Detected

TABLE 6

Occurrence of isolated bacteria in selected organs of Clarias gariepinus exposed to chronic concentrations of MSW leachate from Amoyo waste dumpsite, llorin, Nigeria

\begin{tabular}{|c|c|c|c|c|c|c|c|c|c|c|c|c|c|c|c|}
\hline \multirow{2}{*}{ Bacteria } & \multicolumn{3}{|c|}{ Day 0} & \multicolumn{3}{|c|}{ Day 7} & \multicolumn{3}{|c|}{ Day 14} & \multicolumn{3}{|c|}{ Day 21} & \multicolumn{3}{|c|}{ Day 21} \\
\hline & G & M & $S$ & G & M & $S$ & G & $M$ & $S$ & G & M & $S$ & G & & M S \\
\hline B. subtilis & - & & & T & + & & + & + & + & $r^{-}+2$ & + & + & + & & + \\
\hline subtilis & 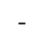 & & 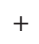 & + & + & & + & + & + & + & + & + & + & + & + \\
\hline hige & + & - & + & + & + & & + & + & + & + & + & + & + & + & + \\
\hline aeruaingsa & & & - & + & - & & + & - & + & + & - & + & + & - & - \\
\hline & + & - & + & + & + & & + & + & + & + & + & + & + & & + \\
\hline nings & & - & - & + & - & & + & - & + & + & - & + & + & & - \\
\hline aureus & + & - & + & + & - & & + & - & + & + & - & + & + & & - \\
\hline eus & + & - & + & + & - & + & + & - & + & + & - & + & + & & - \\
\hline bauma & - & - & - & - & + & & - & + & - & - & + & - & - & & + \\
\hline aeruginosa & - & - & - & + & - & + & + & - & + & + & - & + & + & & - \\
\hline baumar & - & - & - & - & + & - & - & + & - & - & + & - & - & & + \\
\hline subtilis & - & - & + & + & + & + & + & + & + & + & + & + & + & & + \\
\hline eus & + & - & + & + & - & + & + & - & + & + & - & + & + & - & - \\
\hline B. subtilis & - & - & + & + & + & + & + & + & + & + & + & + & + & + & + \\
\hline Micrococcus sp. & - & - & - & - & + & & - & + & - & - & + & - & - & & + \\
\hline K. pneumoniae & + & - & + & + & + & 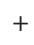 & + & + & + & + & + & + & + & & + \\
\hline E. coli & + & - & 1 & + & + & & + & 1 & + & + & + & + & + & + & + \\
\hline E. coli & + & 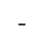 & + & + & + & + & + & + & + & $T$ & + & + & + & & + \\
\hline . & - & - & - & - & + & & - & + & - & - & + & - & - & & + \\
\hline aer & 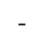 & - & - & + & - & & + & - & + & + & - & + & + & - & - \\
\hline coli & + & - & + & + & + & & + & + & + & + & + & + & + & & + \\
\hline aur & + & - & + & + & - & & + & - & + & + & - & + & + & - & - \\
\hline aerugin & - & - & - & + & - & & + & - & + & + & - & + & + & - & - \\
\hline icro & - & - & - & - & + & & - & + & - & _ & + & - & - & + & + \\
\hline E. coli & + & - & 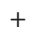 & + & + & & . & + & + & 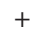 & + & + & + & & + \\
\hline S. ab & + & - & + & + & - & & + & - & + & + & - & + & + & - & - \\
\hline coli & + & - & . & + & + & & + & + & + & + & + & + & + & + & + \\
\hline
\end{tabular}

$\mathrm{G}=$ gills; $\mathrm{M}=$ muscles; $\mathrm{S}=$ skin; + present; - absent. by the European Union (EU) for good water quality that will enhance the survival of fishes and other aquatic organisms, since BOD value for unpolluted waters is usually $\leq 2 \mathrm{mg} / \mathrm{l}$; while values for polluted ones could be as high as $\geq 10 \mathrm{mg} / \mathrm{l}$. The COD value recorded also exceeded the permissible level $(\leq 20 \mathrm{mg} / \mathrm{l})$ for unpolluted water, but falls within the category $(20-200 \mathrm{mg} / \mathrm{l})$ of polluted waters (Chapman, 1996). The values obtained for the metals investigated except copper are considered to be very high and above the NIS (2007) and WHO (2011) standards. The presence of high levels of heavy metals investigated in the leachate indicates that their source could be traced to the deposition of various wastes containing such metals into the landfill/dump site (Aderemi et al., 2012). Elevated levels of $\mathrm{Pb}$ is indicative of disposal of large quantities of lead-based solid wastes such as battery components, paint containers, cosmetic containers, gasoline containers, plastics and pipes found at the site. The preponderance of $\mathrm{Fe}$ in leachate has been reported by Aderemi et al. (2012), suggesting that Fe-rich scraps are constantly being dumped in the landfill. The presence of batteries and paint containers may also explain the elevated values of $C d$, while the presence of fluorescent tubes, electricity bulbs, batteries, food wastes and the burning of tires in the landfill could be responsible for the elevated value of $\mathrm{Zn}$. The values obtained for all the aforementioned metals are considerably high and are above the NIS and WHO standards for surface waters. The improper waste disposal system and the lack of adequate collection and/or treatment facilities might have largely been responsible for the presence of high levels of metals and other organic and inorganic chemicals in the MSW-leachate.

Changes in haematological parameters of $C$. gariepinus: The study shows that the release of leachate 
into water bodies could lead to the formation of reactive oxygen species which could cause oxidative damage to the fish. Haematological parameters such as RBC, HB, PCV, WBC and others have widely been used as veritable tools in the assessment of environmental quality, water pollution and health status of aquatic organisms (Ayandiran \& Dahunsi, 2016). The significant decrease in the values of RBC, HB and PCV at the highest concentration of leachate compared with the control suggests anaemic condition. The haemolysing effect of the leachate on the RBC might have interfered with haemoglobin synthesis pathways, causing a reduction in the oxygen that could be made available to the tissues. However, the non-significant difference $(p>0,05)$ in the parameters relating to oxygen transport $(\mathrm{HB}, \mathrm{PCV}, \mathrm{MCV}, \mathrm{MCH}$ and MCHC) of leachate-exposed fish at 20,00 and 25,00\% treatments appear to be due to the resilient ability of the fish to withstand the stress-induced leachate. Catfishes, the group to which C. gariepinus belong, generally have the ability to tolerate extreme environmental conditions partly due to the possession of accessory breathing organs with which they maintain link with atmospheric oxygen to satisfy their oxygen requirement under hypoxic conditions (Adeyemi, 2015). This may explains why they are mostly cultured and used as bioindicator species in pollution monitoring. The non-significant changes in oxygen transport parameters of fish in this study agrees with the observation of Adeyemi (2015) on C. gariepinus exposed to varying concentrations of simulated leachates. WBC plays an important role in the immune system of living organisms. The observed significant $(p<0,05)$ leachate-inducing effect exerted on WBCs, neutrophils and eosinophils among fishes in all the treatments relative to the control might be a defensive and protective response to cellular damage due to intoxication. The lymphocytes and monocytes significantly decreased at the lowest concentration of leachate. Heavy metals are one of the most serious pollutants due to their persistence and tendency to accumulate in aquatic environment (Ensibi \& Daly-Yahia, 2017). They have been implicated to cause serious debilities to organ and disruption of homeostasis. The release of leachate into water bodies is of serious public health concern, as small amount of leachate could pollute large volume of surface waters (Matejczyk, Plaza, Natecz-Jawecki, Ulfig, \& MarkowskaSzczupak, 2011). The presence of the mixed-metals ( $C d$, $\mathrm{Cu}, \mathrm{Fe}, \mathrm{Pb}, \mathrm{Mn}$ and $\mathrm{Zn}$ ) in Amoyo landfill leachate might have been responsible for the biochemical, cellular and physiological alterations in the leachate-exposed fish due to their antagonistic or synergistic interference with the fish's normal biomolecules. The accumulation of the mixed-metals in the gills and their subsequent passage through systemic circulation could have led to their conversion to stable oxidation states, thus combining with biomolecules such as proteins and enzymes forming a stable bond, hence difficult to be metabolised and may negatively affect respiratory function.

\section{Changes in biochemical parameters of C. gariepi-} nus: Protein, an important constituent of cells and tissues plays a vital role in the physiology of organisms. The significant reduction of protein in all the tissues of leachate-treated fish indicates that the efficiency of the liver in protein synthesis and/or the absorptive capacity of the tissues was compromised following treatment with leachate. It could also be due to the utilization of protein as alternative energy source under stress condition (Owolabi \& Omotosho, 2017) as reflected in the reduction of glycogen in the gills and liver of leachate exposed fish (Table 3). Transaminases (ALT and AST) are localized in periportal hepatocytes and play an important role in amino acid metabolism and increase in these enzymes suggests tissue damage (Aita, 2014). The significantly elevated serum levels of the transaminases could have been due to cellular damage to the membranes of the branchial and hepatic tissues and subsequent leakage of the enzymes from both tissues into the serum, thus lowering the levels of the enzymes. Similar elevated levels of serum ALT and AST in the tissues of simulated leachate-exposed C. gariepinus have earlier been reported (Adeyemi, 2015). LDH is a hydrogen transferring enzyme that catalyses the oxidation of lactate to pyruvate with the mediation of $\mathrm{NAD}^{+}$as hydrogen acceptor. It is often used as a marker of tissue breakdown (El Gohary, Laila, \& Genena, 2011) as it exhibits increased activity under hypoxic conditions. The dynamics of LDH profile in the gills and liver of leachate-exposed fish in this study agrees with this pattern of increased activity (Table 3 ); and this could be attributable to a transition from aerobic to anaerobic metabolism in order to facilitate the conversion of pyruvate, the end product of glycolysis, to lactate that can be used to cope with energy demand under hypoxic condition. Increased LDH activity in fish tissues exposed to cyanide effluents (Alavandi \& Hosetti, 2013) has been reported.

One of the first lines of defense against oxygen free radical is an antioxidant, superoxide dismutase (SOD). SOD catalyses the dismutation of superoxide radicals to oxygen $\left(\mathrm{O}_{2}^{-}\right)$and hydrogen peroxide $\left(\mathrm{H}_{2} \mathrm{O}_{2}\right)$, and a decrease in its activity changes the redox potential of the cells. Thus, under oxidative stress a rise in the activity of this enzyme raises the possibility of initiating adaptive mechanism to eliminate the induction of reactive 
oxygen species (ROS) in fish exposed to xenobiotics. The increased activity of SOD in all the tissues investigated (serum, gill and liver) in this study (Table 3 ) suggests the production of more oxygen free radicals which activates SOD induction in these tissues to counteract the toxic effect of the leachate or its metabolites and thus protect the cells from damage. This result is in agreement with the findings of Arojoye and Farombi (2013) who found that leachate increased the activity of SOD in albino rats; but in contrast to the observations of Bakare, Alimba, and Alabi (2013). Malondialdehydes (MDA) are products of lipid degradation (LPO) and are considered as indicators of oxidative stress resulting from peroxidative injury, which may interfere with the structural cell membrane components. Xenobiotics alter the permeability of cell membrane by stimulating the lipid peroxidation process resulting in sequences of biochemical reactions. LPO has been extensively used as biomarkers of toxic pollutants in fish (Owolabi \& Omotosho, 2017). In this study, MDA levels in the tissues of leachate-treated fish significantly increased compared to the control indicating the susceptibility of these tissues to oxidative attack in the presence of ROS due to the abundance of polyunsaturated fatty acids in their membranes. However, it appears that increased formation of ROS in these tissues commensurate with an increased antioxidant (i.e. SOD) capacity of the tissues; thereby reducing the susceptibility of the tissues to oxidative attack by ROS. This is similar to previous reports that demonstrated an increased ROS formation due to lipid peroxidation in the tissues of leachate-exposed mussels (Tsarpali \& Dailianis, 2012). The higher levels of MDA in the gills could be attributed to the accumulation of higher quantity of the mixed pro-oxidant metals contained in the leachate, which inhibit the scavenging potentials of superoxide anions by SOD making the gills more vulnerable. The gill is the first organ with which fish maintains contact with its environment and is one of the target organs to suffer instantaneously from the ambient toxicants (Shepard, 1994). Hence, the close proximity of the gills to the leachate more than the liver might have enhanced the leachate pro-oxidant metals to have permeated the gill region than any other parts. This observation is in contrast to the observation of Jumawan, Salunga, and Catap (2010) who reported that the gill of the catfish, Pterygoplichthys showed the least level of MDA; suggesting that respiratory function was not significantly affected by lipid peroxidation. AChE is an important enzyme needed for proper functioning of the nervous system of organisms. Therefore, the measurement of its activities in organisms has been widely used as biomarker of lethal poisoning by neurotoxic chemicals. In a tissue-specific pattern, the present study showed that AChE activity was activated in the blood and liver of leachate-exposed fish as opposed to its inhibition in the gills. The presence of abundant anticholinesterase substances in the leachate absorbed by the gill more than other tissues might have been responsible for the inhibition. This is also similar to the report of Tsarpali and Dailianis (2012). The inhibitory impact of these substances on the gills' AChE activity may cause loss of functional integrity to the neuronal cell membrane of the leachate-exposed fish through excess free radical formation and this could threaten the survival of the fish.

Bacteriological profile of C. gariepinus: The bacteria isolated from the leachate and organs of C. gariepinus were species from seven genera; Bacillus, Klebsiella, Acinetobacter, Pseudomonas, Staphylococcus, Escherichia and Micrococcus. The samples were positive for potential pathogenic species and toxin producing organisms. The bacterial load of the gill was higher than the other parts of the fish with the least in the muscle. While microorganisms occur in large numbers on the skin, digestive tract and gills of healthy fish, they are not expected to be found in the fish muscle (Austin, 2006). However, some bacteria were isolated from the muscle of the fish in this study (Tables 4 \& 5). Buras et al. (1987) reported that bacteria were isolated from the fish muscle when the pond water was heavily polluted and the concentration

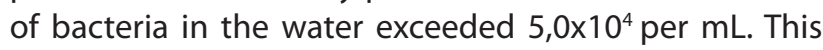
was called 'critical concentration'. The poor water quality occasioned by presence of leachate may have induced weakness in the fish, resulting in greater susceptibility to bacterial infection (Escher, Wahli, Buttner, Meicr, \& Burkhardt-Holm, 1999). This stress accompanied by low oxygen content can also result in high mortality in fish through susceptibility of the fish to bacterial infection (Bunch \& Bejerano, 1997). This correlates with the high WBC count observed in the fish (Table 2) which suggests that the fish were not healthy. A few other workers have also reported the presence of bacteria in fish muscle (Ogbondeminu \& Okoye, 1992), heart, kidney and liver (Toranzo et al., 1993). The higher contamination of the gills in comparison to the other organs sampled may be due to the structure of the gills which may have more specific surfaces for bacterial attachment, in addition to the high volume of water passing through them (ElShafai, Gijzen, Nasr, \& El-Gohary, 2004). Gram negative rod shaped bacteria dominated all the populations. An observation of note was that some of the organisms isolated from the exposed fish were absent in the control fish (Table 5). Such organisms were transferred to the fish from the leachate as a result of the breaking down of the skin barrier caused by the toxicity of the leachate and 
the fish taking in some of the water in which they were cultivated. The highest total viable count was recorded in the gill, then the skin and finally the muscle with the least (Table 5). The bacterial count in the selected organs of the fish was above the permissible count according to Internal Commission on the Microbiology Specification of Foods. The permissible count of bacteria in $1 \mathrm{~cm}^{2}$ of skin ranges from $10^{2}-10^{7}$ or bacteria of $\log 10 \mathrm{CFU} /$ $\mathrm{cm}^{2} \leq 5,70$ according to International Commission on the Microbiology Specification of Foods (Adedeji, 2011). However, the European Union Microbiological criteria for foodstuffs standard for fishery products is at $1-10^{1} \mathrm{CFU} / \mathrm{g}$ for E.coli and $10^{2}-10^{3} \mathrm{CFU} / \mathrm{g}$ for coagulase positive staphylococci (OJEU, 2005). Bacillus subtilis was not recovered from the gills and muscle of the fish at zero hour exposure to different concentrations of the leachate and later isolated at other days. This implied that Bacillus subtilis was not present in the fish and it was transferred to fish from the leachate. Its absence at zero hour could be because the fish had not had enough contact with the leachate water and the organisms were yet to gain entry and establish themselves in the gill and muscle. However, this organism was recovered from the skin at zero hour because the skin had direct contact with the leachate.

Micrococcus sp. was not detected in the leachate but present in the muscle and absent in the gills and skill as well. It could be inferred that Micrococcus is a resident flora in the muscle. Although fish muscles have been considered by some researchers to be sterile (Apun, Yusof, \& Jugang, 1999), other authors have reported the presence of bacteria in them (Alikunhi, Batang, AlJahdali, Aziz, \& Al-Suwailem, 2016). Escherichia coli was the most predominated isolate recovered from this study and occurred mostly in the gill, followed by the skin and least in the muscle (Table 5). This implied that the leachate contained faecal matter. Faecal coliforms in fish demonstrate the level of pollution in their environment because coliform are not named flora of bacteria in fish (Adedeji, 2011). The detection of faecal coliforms in this study conforms to the study carried out by Oshode et al. (2008). This poses a serious danger to human health since pathogenic E. coli are known to cause life threatening foodborne diseases. Klebsiella and Bacillus were recovered from the gills of $C$. gariepinus which is similar to the results of Kumar, Surendran, and Thampuran (2009). This constitutes a food safety problem because the fish could be potential agent of transfer of these organisms to unsuspecting consumers should the leachate be washed into waterbodies. Aeromonas hydrophila and Vibrio sp. which are ubiquitous in aquatic environment and which are common fish pathogens (Hathe et al., 2005) were not recovered in this study.
Out of the three organs analyzed, the gills and the skin had higher microbial load than the muscle which indicated that the test organism bioaccumulated high concentration of the leachate in their gills and skin than in the muscle. This observation is in agreement with the trend of microbial colonization described by Austin (2006). In general, the total viable count was higher than the coliform count and was concentration dependent for the gill, muscle and skin of the exposed fish. The muscle recorded the lowest microbial count because the muscle is not exposed directly to the leachate. The organisms that were isolated gained entry into the fish through the damaged skin since the organisms were not isolated from the control fish. Since E. coli is present in leachate, it is an indication that human intestinal pathogens can gain entrance into the fish. Some bacterial genera isolated in this study, including Bacillus and Pseudomonas sp., have been associated with fish spoilage. The spoilage bacteria in the fish are part of the natural flora of the external slime and intestinal content. The presence of these bacteria in the gill and skin of $C$. gariepinus may be responsible for the early deterioration of the fish as soon as they are taken out of water. This has made the preservation of C. gariepinus more difficult than other fish species. Although Bacillus sp. are harmless saprophytes, many form extracellular proteases that hydrolyze proteins leading to food spoilage (Creusot \& Gruppen, 2008). Moreover, because of the heat resistance of the endospore Bacillus sp. may survive inadequate heat treatment during cooking or smoking of $C$. gariepinus. This is due to the fact that the endospores formed by Bacillus are extremely resistant to desiccation, staining, disinfections, chemicals, radiation and heat (Olojo et al., 2010).

Histopathological changes in the tissues of $C$. gariepinus: The histopathological changes in fish tissues are a very sensitive method of assessing toxicological effect of xenobiotics in fish. The degenerations observed in the branchial cells and hepatocytes of leachate-exposed fish fall within the general responses of fish tissues to contaminants. This may be linked to the presence of metals contained in the leachate and were probably adaptation to cope with the challenges of the toxicant. The hyperplasia and abnormal gill tip due to fusion and swelling of lamellae in the leachate-treated fish were attempts to reduce available surface area to the leachate. However, the reduction in gill surface area may lead to hypoxia. This result supports several observations which reported that fish exposed to $\mathrm{Cd}, \mathrm{Cu}, \mathrm{Fe}, \mathrm{Pb}, \mathrm{Mn}$ and $\mathrm{Zn}$ and other heavy metals and contaminants resulted in histopathological changes (Randi, Monserrat, Rodriguez, \& Romano, 1996). This result is also similar to the report of Pribadi, 
Syahidah, Harjanti, and Malini (2017) on Cyprinus carpio exposed to leachate. Severe necrosis observed at higher concentration of leachate might have resulted from the effort to get rid of the toxicant and the failed attempt to regenerate new cells. Furthermore, the histopathological lesions observed in the gill and liver of leachate-treated fish might have been responsible for the seepage of ALT and AST into the serum, hence their low levels in these tissues. The lesions might have also accounted for the alterations in carbohydrate and protein metabolism, which in turn caused significant changes in the activities of ALT, AST and LDH in order to meet the demand of energy needed to survive under hypoxic stress. Similar trends in transaminases' and LDH activities were evident in the tissues of fish exposed to toxicant (Ramesh, Sankaran, Veera-Gowtham, \& Poopal, 2014).

In conclusion, the present study shows that exposure to sublethal concentrations of leachate induced haemato-chemical and histological responses in C. gariepinus, with the gills adversely affected than the liver. The changes in haemato-chemical parameters can lead to improper homeostasis and impaired metabolic processes. These results may be useful in the assessment of toxic impact of leachate on fish.

\section{REFERENCES}

Adedeji, O.B. (2011). Bacterial load in African catfish and Nile Tilapia sampled from ponds and natural Water. Journal of Microbiology and Biotechnology Research, 1(1), 52-59.

Aderemi, A.O., Adewumi, G.A., \& Otitoloju, A.A. (2012). Municipal landfill leachate characterisation and its induction of glycogen vacuolation in the liver of Clarias gariepinus. International Journal of Environmental Protection, 2(4), 20-24.

Adewoye, S.O., \& Adegunlola, G.A. (2010). Microbiological Investigation of selected organs of Clarias gariepinus exposed to wastewaters from a detergent Industry. Advances in Applied Science Research, 1(1), 9-13.

Adeyemi, O. (2015). Leachate simulated from municipal open dump induces biochemical changes in Clarias gariepinus. Research and Reviews in Biosciences, 10(1), 8-15.

Aita, N.A.A. (2014). Genotoxic, Hematological and Biochemical Changes Induced by Phenol Exposure in African Catfish (Clarias gariepinus). Global Veterinaria, 13(3), 316-324.

Alavandi, S., \& Hosetti, B.B. (2013). Influence of cyanide on some antioxidant enzymes of freshwater fish, Cirrhinus mrigala (Hamilton). Journal of Agricultural Science, 58(3), 177-184.

Alikunhi, N.M., Batang, Z.B., AlJahdali, H.A., Aziz, M.A.M., \& Al-Suwailem, A.M. (2016). Culture-dependent bacteria in commercial fishes: Qualitative assessment and molecular identification using 16S rRNA gene sequencing. Saudi Journal of Biological Science, 24(6), 11051116. DOI: 10.1016/j.sjbs.2016.05.017

APHA (American Public Health Association). (1998). Standard methods for the examination of water and wastewater ( $20^{\text {th }}$ ed.). Washington D.C., USA: American Public Health Association.

Apun, K., Yusof, A.M., \& Jugang, K. (1999). Distribution of bacteria in tropical freshwater fish and ponds. International Journal of Environmental Health Research, 9, 285.292. DOI: 10.1080/09603129973083

Arojojoye, O., \& Farombi, E.O. (2013). Biochemical evaluation of oxidative damage induced by municipal landfill leachate in the liver and kidney of albino rats. Archive of Basic and Applied Medicine, 1(1), 93-102.

Austin, B. (2006). The bacterial microflora of fish, revised. The Scientific World Journal, 6, 931-945. DOI: 10.1100/ tsw.2006.181

Ayandiran, T.A., \& Dahunsi, S.O. (2016). Toxicological Assessment of fish (Clarias gariepinus) from bitumen-polluted River. Environmental Monitoring and Assessment, 188(71), 1-18. DOI: $10.1007 / \mathrm{s} 10661-015-5003-7$

Bakare, A.A., Alabi, O.A., Gbadebo, A.M., Ogunsuyi, O.I., \& Alimba, C.G. (2013). In vivo cytogenotoxicity and oxidative stress induced by electronic waste leachate and contaminated well water. Challenges, 4, 189-187. DOI: 10.3390/challe4020169

Bakare, A.A., Alimba, C.G., \& Alabi, O.A. (2013). Genotoxicity and mutagenicity of solid waste leachates: A review. African Journal of Biotechnology, 12(27), 4206-4220. DOI: 10.5897/AJB2013.12014

Budi, S., Suliasih, B.A., Othman, M.S., Heng, L.Y., \& Surif, S. (2016). Toxicity identification evaluation of landfill leachate using fish, prawn and seed plant. Waste Management, 55, 231-7. DOI: 10.1016/j.wasman.2015.09.022

Buege, J.A., \& Aust, S.D. (1978). Microsomal lipid peroxidation. Methods in Enzymology, 52, 302-310. DOI: 10.1016/ S0076-6879(78)52032-6

Bunch, E.C. \& Bejerano, I. (1997). The effect of environmental factors on the susceptibility of hybrid tilapia Oreochromis niloticus $\mathrm{x}$ Oreochromis aureus to streptococcosis. Bamidgeh, 49, 67-76.

Buras, N., Duek, L., \& Niv, S. (1985). Reactions of fish to microorganisms in wastewater. Applied and Environmental Microbiology, 50(4), 989-995.

Buras, N., Duek, L., Niv, S., Hepher, B., \& Sandbank, E. (1987). Microbiological aspects of fish grown in treated wastewater. Water Research, 21, 1-10.

Chapman, D. (1996). Water quality assessment: a guide to the use of biota, sediments and water in environmental monitoring ( $2^{\text {nd }}$ ed.). London, UK: Chapman and Hall. DOI: 10.4324/NOE0419216001 
Christensen, T.H., Kjeldsen, P., Bjerg, P.L., Jensen, D.L., Christensen, B.J., Baum, A. ... Heron, G. (2001). Biogeochemistry of landfill leachates plumes. Applied Geochemistry, 16, 659718. DOI: 10.1016/S0883-2927(00)00082-2

Clark, S., Whitmore, D.H., \& McMahon, R.F. (1979). Considerations of blood parameters of largemouth bass, Micropterus salmoides. Journal of Fishery Biology, 14, 147-158. DOI: 10.1111/j.1095-8649.1979.tb03504.x

Creusot, N., \& Gruppen, H. (2008). Hydrolysis of whey protein isolate with Bacillus licheniformis protease: aggregating capacities of peptide fractions. Journal of Agriculture and Food Chemistry, 12(56), 10332-10339. DOI: 10.1021/ jf801422j

Dacie, J.V., \& Lewis, S.M. (2001). Practical Haematology ( $9^{\text {th }}$ ed.). London: Churchil Livingstone.

DGKC (Deutsche Gesellschaft fur Klinische Chemie). (1970). The standard method for analysing lactate dehydrogenase enzyme. Journal of Clinical Chemistry and Clinical Biochemistry, 8, 658-659.

Dos Santos Miron, D., Shettinger, M.R., Morsh, V.M., Baldisserotto, B., Tierno, M.A., Moraes G., \& Vieira V.L.P. (2005). Effects of the herbicides clomazone, quinclorac and metsufuron methyl on acetylcholinesterase activity in the silver catfish (Rhamida quelen, Heptateridae). Ecotoxicology and Environmental Safety, 61(3), 398-403. DOI: 10.1016/j. ecoenv.2004.12.019

El Gohary, A., Laila, R.A., \& Genena, M.A.M. (2011). Biochemical effects of three molluscan baits against the two land snails, Monacha cantiana and Eobania vermiculata (Gastropa: Helicidae). International Journal of Agricultural Research, 6(9), 682-690. DOI: 10.3923/ijar.2011.682.690

El-Shafai, S. A., Gijzen, H. J., Nasr, F. A., \& El-Gohary, F. A. (2004). Microbial quality of tilapia reared in faecal contaminated ponds. Environmental Research, 95, 231-238. DOI: 10.1016/j.envres.2004.01.002

Ensibi, C., \& Daly-Yahia, M.N. (2017). Toxicity assessment of cadmium chloride on planktonic copepods Centropages ponticus using biochemical markers. Toxicological Reports, 4, 83-88. DOI: 10.1016/j.toxrep.2017.01.005

Escher, M., Wahli, T., Buttner, S., Meicr, W., \& Burkhardt-Holm, P. (1999). The effect of sewage plant effluent on brown trout (Salmo trutta Fabrio): a cage experiment, Aquatic Sciences, 61, 93-110. DOI: 10.1007/s000270050055

Glusczak, L., Loro, V. L., Pretto, A., Moraes, B. S., Raabe, A., Duarte., M.F., ... de Sousa Valladão, D. M. (2011). Acute exposure to glyphosate herbicide affects oxidative parameters in Piava (Leporinus obtusidens). Archives of Environmental Contamination and Toxicology, 61(4), 624-630. DOI: 10.1007/s00244-011-9652-4

Hatha, M., Vivekanandhan, V.G., Joice, J., \& Christol, V. (2005). Antibiotic resistance pattern of motile aeromonads from farm raised freshwater fish. International Journal of Food Microbiology, 98, 131-134
Ibrahim, S.I., Awomuti, A.A., \& Ajibade, L.T. (2012). Storage and treatment system of solid waste as strategy for sustainable environmental development in Ilorin Metropolis, Nigeria. Advances in Applied Science Research, 3(2), 801-808.

Imoh, E.U., \& Udofia E.P. (2011). Domestic solid waste management in a rapidly growing Nigerian city of Uyo. Journal of Human Ecology, 36(3), 229-235

Jumawan, J.C., Salunga, T.P., \& Catap, E.S. (2010). Lipid peroxidation and patterns of cadmium and lead accumulation in the vital organs of the suckermouth armored catfish, Pterygoplichthys gill, from Marikina River. Journal of Applied Science and Environmental Sanitation, 5(4), 375-390.

Kulikowska, D., \& Klimiuk, E. (2008). The effect of land age on municipal leachate composition. Bioresource Technology, 99, 5981-5985. DOI: 10.1016/j.biortech.2007.10.015

Kumar, R., Surendran, P.K., \& Thampuran, N. (2009). Distribution and genotypic characteristics of Salmonellar serovars isolated from tropical seafood of Cochin, India. Journal of Applied Microbiolology, 106, 515-524. DOI: 10.1111/j.1365-2672.2008.04020.x

Kurniawan, T.A., Lo, W.H., \& Chan, G.Y.S. (2006). Physico-chemical treatments for removal of recalcitrant contaminants from landfill leachates. Journal of Hazard Material, 129(13), 80-100. DOI: 10.1016/j.jhazmat.2005.08.010

Laneret, D., Crest, M., Scharff, H., Morris, J. W., \& Barlaz, M. A. (2012). A review of approaches for the long-term management of municipal solid waste landfills. Waste Management, 32(3), 498-512. DOI: 10.1016/j. wasman.2011.11.010

Lenette, E.H., Albert, B., \& Willian, J.H. (1985). Manual of Clinical Microbiology ( $4^{\text {th }}$ ed.). Washington, D.C., USA: American Society for Microbiology.

Lowry, O.H., Rosebrough, N.J., Farr, A.L., \& Randall, R.J. (1951). Protein measurement with the folin phenol reagent. Journal of Biological Chemistry, 193(1), 265-275.

Matejczyk, M., Plaza, G.A., Natecz-Jawecki, G., Ulfig, K., \& Markowska-Szczupak, A. (2011). Estimation of the environmental risk posed by landfills using chemical, microbiological and ecotoxicological testing of leachates. Chemosphere, 82, 1017-1023. DOI: 10.1016/j. chemosphere.2010.10.066

McBean, A, Rovers, F.A., \& Farquhar, G.J. (1995). Solid waste landfill engineering and design. New York: Prentice Hall PTR.

Misra, H., \& Fridovish, I. (1972). Determination of the level of superoxide dismutase in whole blood. Yale University Press, 101(1972), 109.

NESREA. (2011). National Environmental (Surface and Ground Water Quality Control) Regulations (Legislation). Nigeria: FAO.

NIS (Nigerian Industrial Standard). (2007). Nigerian standards for drinking water quality. (NIS 554: 2007, ICS 13.060.20). 
Standard Organisation of Nigeria (SON) Governing Council.

Nordenson, N. (2004). White blood cell count and differential analysis. Environmental Health Perspective, 9, 211-221.

Official Journal of the European Union (2005). Microbiological criteria for foodstuffs. Retrieved from https://www.fsai. ie/uploadedFiles/Reg2073_2005(1).pdf

OgboOgbondeminu, F.S., \& Okoye, F.C. (1992). Microbiological evaluation of an untreated domestic wastewater aquaculture system. Journal of Aquaculture in the Tropics, 7, 27-34.

Oliveira, L.F., Silva, S.M., \& Martinez, C.B.R. (2014). Assessment of domestic landfill leachate toxicity to the Asian clam Corbicula fluminea via biomarkers. Ecotoxicology and Environmental Safety, 103, 17-23. DOI: 10.1016/j. ecoenv.2014.01.034

Olojo, E.A.A., Amusa, N.A., Osho, A., \& Badejo, V.O. (2010). Commensal bacterial flora of Synodontis nigrita and Clarias gariepinus from River Osun, South west Nigeria, Nigeria. Research Journal of Applied Science, 5, 231-235. DOI: 10.3923/rjasci.2010.231.235

Olugbojo, J.A., \& Ayoola, S.O. (2015). Comparative studies of bacterial load in fish species of commercial importance at the Aquaculture unit and lagoon front of the University of Lagos. International Journal of Fisheries and Aquaculture, 7(4), 37-46. DOI: 10.5897/IJFA14.0444

Oshode, A., Bakare, A.A., Adeogun, A.O., Efuntoye, M.O., \& Sowunmi, A.A. (2008). Ecotoxicological assessment using Clariasgariepinus and microbial characterization of leachate from municipal solid waste landfill. International Journal of Environmental Research, 2(4), 391-400.

Owolabi, O.D (2011). Haematological and serum biochemical profile of the upside-down catfish Synodontis membranacea Geoffroy Saint Hilaire from Jebba Lake, Nigeria. Comparative Clinical Pathology, 20, 163-172 DOI: 10.1007/s00580-10-0973-x

Owolabi, O.D., \& Omotosho, J.S. (2017). Atrazine-mediated oxidative stress responses and lipid peroxidation in the tissues of Clarias gariepinus. Iranian Journal of Toxicology, 11(2), 29-38. DOI: 10.29252/arakmu.11.2.29

Pribadi, T.D.K., Syahidah, D., Harjanti, S.D., \& Malini, D.M. (2017). Alteration of gill and liver histological structure of Cyprinus carpio exposed to leachate. Biosaintifika: Journal of Biologyand Biology Education, 9(2), 287-297. DOI: 10.15294/biosaintifika.v9i2.8972
Ramesh, M., Sankaran, M., Veera-Gowtham, V., \& Poopal, R.K. (2014). Haematological, biochemical and enzymological responses in an Indian major carp Labeo rohita induced by sublethal concentration of water-borne selenite exposure. Chemico-Biological interactions, 207, 67-73. DOI: 10.1016/j.cbi.2013.10.018

Randi, A.S., Monserrat, J.M., Rodriguez, E.M., \& Romano, L.A. (1996). Histopathological effects of cadmium on the gills of freshwater fish Macropsobrycon uruguayanae (Pisces: Atherinidae). Journal of Fish Diseases, 19(4), 311322. DOI: 10.1046/j.1365-2761.1996.d01-82.x

Reish, D.L., \& Oshida, P.S. (1987). Manual of methods in aquatic environment research, Part 10: short static bioassays. Roma, Italy: Food and Agriculture Organization.

Reitman, S., \& Frankel, S. (1957). Colometric method for the determination of serum transaminase activity. American Journal of Clinical Patholology, 28, 56-68. DOI: 10.1093/ ajcp/28.1.56

Ribé, V., Nehrenheim, E., Odlare, M., Gustavsson, L., Berglind, R., \& Forsberg, A. (2012). Ecotoxicological assessment and evaluation of a pine bark biosorbent treatment of five landfill leachates. Waste Management, 32, 1886-1894. DOI: 10.1016/j.wasman.2012.05.011

Shepard, K.L. (1994). Functions of fish mucus. Reviews in Fish Biology and Fisheries, 4, 401-429. DOI: 10.1007/ BF00042888

Toranzo, A.E., Novoa, B., Romalde, J.L., Nunez, S., Devesa, S., Marino, E., ... Barja, J.L. (1993). Microflora associated with healthy and diseased turbot (Scophthalmus maximus) from three farms in northwest Spain, Aquaculture, 114, 189-202. DOI: 10.1016/0044-8486(93)90295-A

Trinder, P. (1969). Determination of glucose in blood using glucose oxidase with an alternative oxygen acceptor. Annals of Clinical Biochemistry, 6(1), 24-27. DOI: $10.1177 / 000456326900600108$

Tsarpali, V., \& Dailianis, S. (2012). Investigation on landfill leachate toxic potency: An integrated approach with the use of stress indices in tissues of mussels. Aquatic Toxicology, 124-125, 58-65. DOI: 10.1016/j.aquatox.2012.07.008

USEPA (United States Environmental protection Agency). (2011). Source Water Assessment USEPA, Office of water. Retrieved from http://water.epa.gov/infrastructure/ drinking water/sourcewater/protection/sourcewaterassessments.cfm. A

WHO (World Health Organisation) (2011). Guidelines on drinking water quality ( $4^{\text {th }}$ ed.). Geneva, Switzerland:World Health Organisation. 